\title{
First insights into the deep-sea tanaidacean fauna of the Ross Sea: species richness and composition across the shelf break, slope and abyss
}

\author{
Krzysztof Pabis $^{1}$ - Piotr Jóźwiak ${ }^{1}$ - Anne-Nina Lörz ${ }^{2,3} \cdot$ Kareen Schnabel $^{2}$ • \\ Magdalena Błażewicz-Paszkowycz ${ }^{1}$
}

Received: 31 December 2014/Revised: 7 April 2015/Accepted: 10 April 2015/Published online: 3 May 2015

(C) The Author(s) 2015. This article is published with open access at Springerlink.com

\begin{abstract}
Tanaidaceans belong to the most severely underestimated groups of benthic macrofauna of the Southern Ocean. Here, we analyze 11 samples collected with a small-meshed epibenthic sled in the summer season of 2008 , in the Ross Sea, at the shelf break, slope and abyss (365-3490 m). The material was obtained during a RV Tangaroa voyage as part of the New Zealand International Polar Year, Census of Antarctic Marine Life Project. Seventy-two species of Tanaidacea were recorded, $85 \%$ of which were new to science. The most speciose genera are Typhlotanais, Pseudotanais and Paraleptognathia. Rare species (singletons and doubletons) constituted $60 \%$ of the material. Each of the three studied depth zones was characterized by a unique tanaidacean fauna. Only few species $(<6 \%)$ occurred consistently in more than one depth zone. The highest number of species (31 species) was recorded in
\end{abstract}

Electronic supplementary material The online version of this article (doi:10.1007/s00300-015-1706-z) contains supplementary material, which is available to authorized users.

Magdalena Błażewicz-Paszkowycz

magdab@biol.uni.lodz.pl

Krzysztof Pabis

cataclysta@wp.pl

Piotr Jóźwiak

pjozwiak@biol.uni.lodz.pl

1 Laboratory of Polar Biology and Oceanobiology, University of Łódź, Banacha 12/16, 90-237 Łódź, Poland

2 National Institute of Water and Atmospheric Research (NIWA), 301 Evans Bay Parade, Wellington 6021, New Zealand

3 Centrum für Naturkunde (CeNak), Zoologisches Museum, Universität Hamburg, Martin-Luther-King-Platz 3, 20146 Hamburg, Germany the abyssal sites, and the lowest number of species $(20$ species) at the shelf sites.

Keywords Peracarida - Antarctica - Diversity - Bathyal · Abyssal · IPY · CAML

\section{Introduction}

The results of the Census of Antarctic Marine Life (CAML) program have highlighted that a taxonomic inventory of the shelf benthic fauna in the Southern Ocean is still far from complete (De Broyer et al. 2011; Griffiths et al. 2011, 2014) and that the knowledge on the diversity of benthic communities below shelf depth is especially scarce (e.g., Hilbig 2004; Blake and Narayanswamy 2004; Brandt et al. 2007; Kaiser et al. 2007, 2011; Post et al. 2011; Griffiths et al. 2014). The debate about species richness, rarity, level of endemism and distribution patterns is ongoing because wide areas have been sparsely, if ever, sampled (Kaiser et al. 2007, 2009). Recent studies have indicated that the Antarctic slope is an important biodiversity hot spot for benthic fauna (Kaiser et al. 2007, 2011; Pabis et al. 2015), with a unique slope fauna in some regions of the Southern Ocean (Kaiser et al. 2011). Moreover, the Southern Ocean deep sea may provide an early warning system for understanding the effect of global warning on resident marine fauna (Kaiser and Barnes 2008). Therefore, studies on biodiversity, especially in the scarcely sampled deep sea (Griffiths 2010), are vitally important and will contribute not only to the evaluation of the current Southern Ocean fauna, but also allow us to assess the degree of connectivity between its major basins, as well as vulnerability to future environmental changes. 
Comparisons between the shelf, slope and abyssal faunas of the Southern Ocean are so far limited. Each of those zones is governed by different physical and biological forces; thus, differences in composition of those faunas are expected. Shelf benthic communities at depths ranging to over $600 \mathrm{~m}$ are shaped by glacial disturbances (Gutt 2001), while the slope is characterized by a great variety of habitats and is known to have offered refugia for benthic fauna during past glacial periods (Thatje et al. 2005; Barnes 2008). In contrast, variations in food supply are likely to have a major effect on faunal distributions in the abyss (Rex and Etter 2010). Distribution patterns of various taxa along depth gradients may differ depending on hydrostatic pressure tolerance, specific habitat requirements, dispersal ability, development modes and other natural history characteristics (Kaiser et al. 2011; Thatje 2012).

Tanaidaceans are small benthic brooders living in tubes. They have extremely low mobility and are thought to undergo extensive radiation in the deep sea (BłażewiczPaszkowycz et al. 2012; Pabis et al. 2015). Recent assessments suggest that tanaidaceans are one of the most underestimated groups of benthic macrofauna worldwide (Appeltans et al. 2012; Błażewicz-Paszkowycz et al. 2012). In some regions of the Southern Ocean, the number of species new to science reaches even $90 \%$ of the collected material (Pabis et al. 2015).

Knowledge on Tanaidacea of East Antarctica, including the Ross Sea, is limited, especially when compared to the other regions of the Southern Ocean (Błażewicz-Paszkowycz 2014). Although the Ross Sea is probably the most intensively studied region of the Southern Ocean (e.g., Dayton et al. 1974; Dayton and Oliver 1977; Gambi et al. 1997; Berkman et al. 2005; Rehm et al. 2007; Cummings et al. 2010; Schiaparelli et al. 2014), the recognition of its deep-sea biota is far from complete (Clarke et al. 2007). The Ross Sea is one of the Antarctic regions least impacted by human activities, although oceanographic properties and biogeochemical cycles are already altered by climate change (Smith et al. 2012). Therefore, it is considered an ideal site to assess future changes in structure, biodiversity and functioning of benthic communities.

Any earlier studies on Tanaidacea in the Ross Sea were dedicated to their taxonomy (Sieg 1983; Błażewicz-Paszkowycz and Larsen 2005), and the only biodiversity assessment of tanaidacean fauna has concentrated on shelf depths (Błażewicz-Paszkowycz and Siciński 2014; Piazza et al. 2014). The New Zealand International Polar Year CAML project aimed to describe depth-related changes of the Ross Sea benthic fauna from the shelf to abyssal depth (Lörz et al. 2013). Our study analyzes tanaidacean fauna collected in the framework of this program.

\section{Materials and methods}

\section{Study area}

The Ross Sea is a large basin located at the border of East and West Antarctica and lies due south of New Zealand. It is considered the most productive area of the Southern Ocean (Arrigo et al. 2008). The western part of the Ross Sea is a source of the Antarctic Bottom Water (Pardo et al. 2012). The northwestern part of the Ross Sea shelf was not glaciated during the past glacial maximum; thus, the shelf and slope might have served as refugia for benthic fauna (Smith et al. 2012). After the Antarctic Treaty Consultative Meeting (ATCM) in Buenos Aires in 2010, the Ross Sea was included into the network of marine protected areas.

\section{Sampling and data analysis}

Samples were collected in the framework of the New Zealand International Polar Year (IPY) CAML project in the summer season of 2008. Material was sampled by RV Tangaroa (voyage TAN0802) throughout the Ross Sea and two northern seamounts (Admiralty and Scott). Eleven samples, collected using an epibenthic sled (EBS) (Brenke 2005), were analyzed (Fig. 1). Tows were aimed to be for $15 \mathrm{~min}$ bottom time at $<1$ knot towing speed. The sled has two fine-mesh nets $(0.5 \mathrm{~mm}$ mesh size, one above the other, each with rigid plastic cod end containers) and is designed to sample both the macroepifauna as well as the hyperbenthic fauna. Stations were distributed along a depth gradient, from the shelf break to the abyssal plain. Tow length varied from 247 to $1493 \mathrm{~m}$ (Table 1). This sampling gear was already used earlier in the studies of tanaidacean fauna and other peracarids (e.g., Kaiser et al. 2007; Pabis et al. 2015). Four samples were collected on the shelf $(365-524 \mathrm{~m})$, four on the slope $(806-1645 \mathrm{~m})$ and three in the abyssal zone (3212-3490 m). Material was sieved on $0.3 \mathrm{~mm}$ mesh and preserved in $99 \%$ ethanol.

Tanaidaceans were identified to the morphospecies level. The Bray-Curtis formula was used to assess the similarity among the samples. Hierarchical agglomerative clustering based on presence/absence transformed data was done with use of group average grouping method in the PRIMER 6.0 package (Clarke and Warwick 2001). Species accumulation curve averaged over 999 permutations was created using PRIMER 6.0. The percentage of species common to the three investigated depth zones was determined. A number of rare species, defined as singletons (represented by only one individual in the whole material) and doubletons (represented by only two individuals in the whole material), were counted. 
Fig. 1 Distribution of sampling stations (The $1,000 \mathrm{~m}$ isobath is shown in bold)

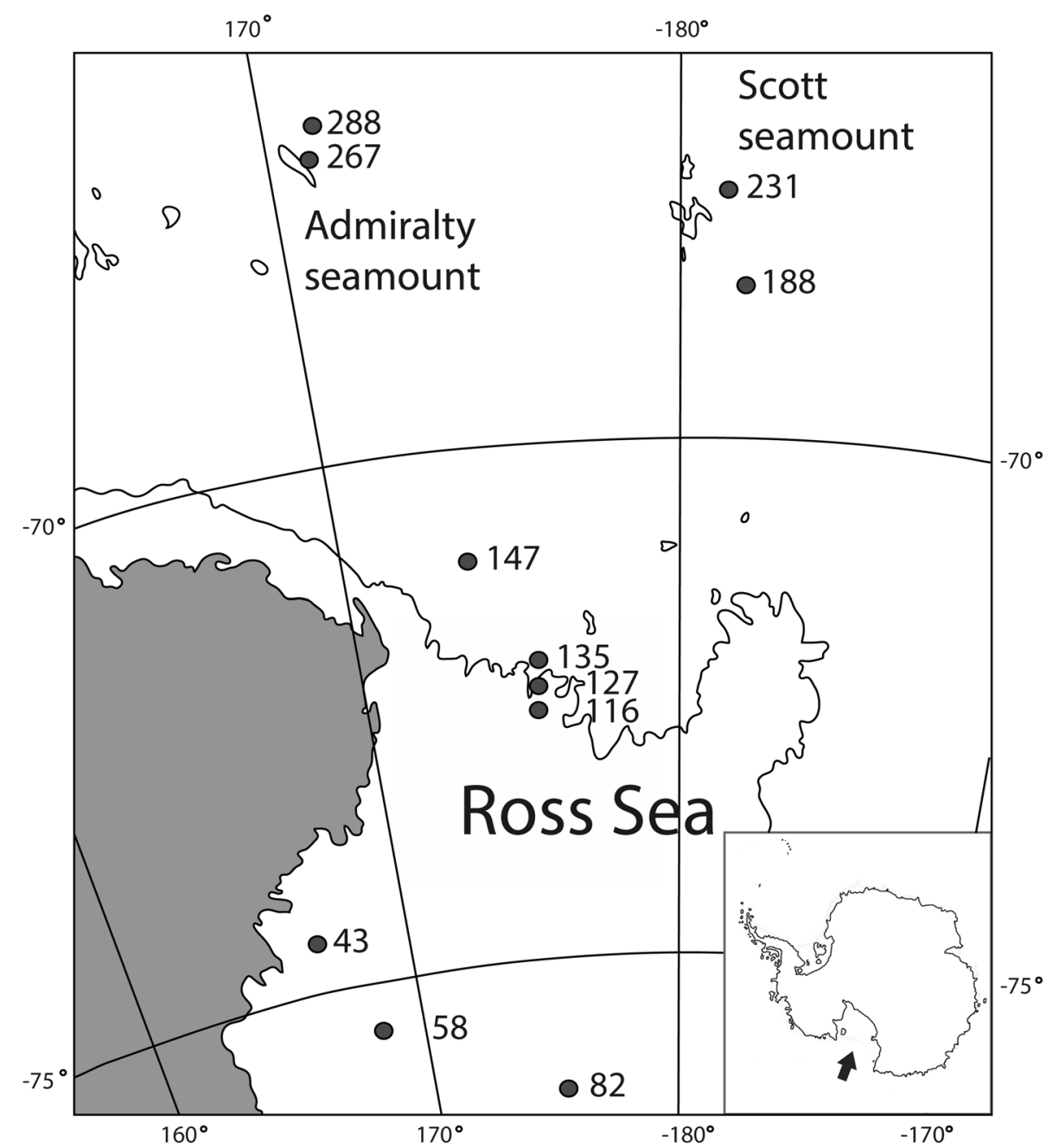

Table 1 Epibenthic sled stations sampled via RV Tangaroa in the western Ross Sea 2008 from the shelf break down to slope and the abyssal plain including information about number of individuals and number of species collected

\begin{tabular}{|c|c|c|c|c|c|c|c|c|c|}
\hline Station \# & Start lat. & Start long. & End lat. & End long. & Max. Depth (m) & Towed distance (m) & $\mathrm{N}$ Ind. & $\mathrm{N}$ Ind./1000 m & $\mathrm{N}$ species \\
\hline 82 & $76^{\circ} 35.46 \mathrm{~S}$ & $176^{\circ} 52.97 \mathrm{~W}$ & $76^{\circ} 35.18 \mathrm{~S}$ & $176^{\circ} 53.38 \mathrm{~W}$ & 364 & 550 & 8 & 14 & 4 \\
\hline 116 & $72^{\circ} 36.22 \mathrm{~S}$ & $175^{\circ} 19.91 \mathrm{E}$ & $72^{\circ} 36.33 \mathrm{~S}$ & $175^{\circ} 20.16 \mathrm{E}$ & 474 & 247 & 9 & 36 & 6 \\
\hline 58 & $75^{\circ} 36.78 \mathrm{~S}$ & $169^{\circ} 47.13 \mathrm{~W}$ & $75^{\circ} 37.52 \mathrm{~S}$ & $169^{\circ} 48.38 \mathrm{~W}$ & 524 & 1493 & 20 & 13 & 10 \\
\hline 267 & $66^{\circ} 58.69 \mathrm{~S}$ & $170^{\circ} 49.79 \mathrm{E}$ & $66^{\circ} 58.74 \mathrm{~S}$ & $170^{\circ} 50.50 \mathrm{E}$ & 503 & 525 & 10 & 19 & 6 \\
\hline 43 & $74^{\circ} 46.41 \mathrm{~S}$ & $167^{\circ} 03.10 \mathrm{~W}$ & $74^{\circ} 46.01 \mathrm{~S}$ & $167^{\circ} 03.14 \mathrm{~W}$ & 806 & 244 & 32 & 131 & 7 \\
\hline 127 & $72^{\circ} 19.01 \mathrm{~S}$ & $175^{\circ} 28.43 \mathrm{E}$ & $72^{\circ} 19.00 \mathrm{~S}$ & $175^{\circ} 28.94 \mathrm{E}$ & 979 & 289 & 26 & 89 & 5 \\
\hline 147 & $71^{\circ} 57.02 \mathrm{~S}$ & $173^{\circ} 23.97 \mathrm{~W}$ & $71^{\circ} 57.21 \mathrm{~S}$ & $173^{\circ} 23.55 \mathrm{~W}$ & 1610 & 428 & 1 & 2 & 1 \\
\hline 135 & $72^{\circ} 04.38 \mathrm{~S}$ & $175^{\circ} 35.13 \mathrm{E}$ & $72^{\circ} 04.77 \mathrm{~S}$ & $175^{\circ} 34.99 \mathrm{E}$ & 1645 & 730 & 44 & 60 & 19 \\
\hline 188 & $68^{\circ} 33.13 \mathrm{~S}$ & $178^{\circ} 22.32 \mathrm{~W}$ & $68^{\circ} 33.64 \mathrm{~S}$ & $178^{\circ} 21.19 \mathrm{~W}$ & 3212 & 1220 & 24 & 19 & 11 \\
\hline 288 & $66^{\circ} 45.51 \mathrm{~S}$ & $171^{\circ} 09.14 \mathrm{E}$ & $66^{\circ} 45.88 \mathrm{~S}$ & $171^{\circ} 09.75 \mathrm{E}$ & 3380 & 820 & 20 & 24 & 9 \\
\hline 231 & $67^{\circ} 37.15 \mathrm{~S}$ & $178^{\circ} 54.71 \mathrm{~W}$ & $67^{\circ} 37.12 \mathrm{~S}$ & $178^{\circ} 56.04 \mathrm{~W}$ & 3490 & 944 & 50 & 52 & 21 \\
\hline
\end{tabular}




\section{Results}

Seventy-two tanaidacean species representing 11 families and 26 genera (244 individuals) were identified in the studied material (Online Resource 1). The majority of the species belong to the order Tanaidomorpha. Only two species represented the suborder Apseudomorpha and one species represented Neotanaidomorpha. Sixty-two species ( $85 \%$ of all species from 20 genera, see Table 2) are new to science. Previously known taxa include: Arthrura monacantha (Vanhöffen, 1914), Cryptocopoides antarctica (Vanhöffen, 1914), Leviapseudes cf. shiinoi (Lang, 1968), Meromonakantha nutae (Błażewicz-Paszkowycz, 2007), Nototanais antarcticus (Hodgson, 1902), Paranarthrura

Table 2 Numbers of Tanaidacea species in each genus (numbers of new species in parentheses) by depth zone, numbers of individuals and depth range

\begin{tabular}{lllllll}
\hline Genus/family & $\begin{array}{l}\text { Shelf } \\
(365-524 \mathrm{~m})\end{array}$ & $\begin{array}{l}\text { Slope } \\
(806-1645 \mathrm{~m})\end{array}$ & $\begin{array}{l}\text { Abyss } \\
(3212-3490 \mathrm{~m})\end{array}$ & $\begin{array}{l}\text { Total } \\
\text { N Spec. }\end{array}$ & $\begin{array}{l}\text { Total } \\
\text { N Ind. }\end{array}$ & $\begin{array}{l}\text { Maximum total } \\
\text { number individuals } \\
\text { of a single species }\end{array}$ \\
\hline
\end{tabular}

\begin{tabular}{|c|c|c|c|c|c|c|c|}
\hline \multicolumn{8}{|l|}{ Agathotanaidae } \\
\hline Paragathotanais & $1(1)$ & $1(1)$ & - & $2(2)$ & 8 & 5 & $524-806$ \\
\hline Paranarthrura & - & $1(0)$ & $3(2)$ & $4(2)$ & 13 & 8 & $1645-3490$ \\
\hline \multicolumn{8}{|l|}{ Akanthophoreidae } \\
\hline Chauliopleona & - & - & $2(2)$ & $2(2)$ & 6 & 4 & $3212-3490$ \\
\hline Paraleptognathia & $4(4)$ & $2(2)$ & $2(2)$ & $7(7)$ & 15 & 4 & $524-3490$ \\
\hline Tumidochelia & $1(1)$ & - & - & $1(1)$ & 1 & 1 & 474 \\
\hline \multicolumn{8}{|l|}{ Apseudidae } \\
\hline Leviapseudes & - & - & $1(0)$ & $1(0)$ & 21 & 21 & $3212-3490$ \\
\hline Zoidbergus & - & $1(1)$ & $1(1)$ & $1(1)$ & 7 & 7 & $1645-3490$ \\
\hline \multicolumn{8}{|l|}{ Colletteidae } \\
\hline Caudalonga & - & - & $1(1)$ & $1(1)$ & 2 & 2 & $3212-3900$ \\
\hline Collettea & - & - & $2(1)$ & $2(1)$ & 3 & 2 & $3380-3490$ \\
\hline Leptognathiopsis & - & - & $2(2)$ & $2(2)$ & 2 & 1 & 3490 \\
\hline \multicolumn{8}{|l|}{ Cryptocopidae } \\
\hline Cryptocopoides & - & $1(0)$ & - & $1(0)$ & 4 & 4 & 979-1645 \\
\hline \multicolumn{8}{|l|}{ Leptognathiidae } \\
\hline Leptognathia & $2(2)$ & $2(2)$ & $2(2)$ & $5(5)$ & 6 & 2 & $524-3490$ \\
\hline \multicolumn{8}{|l|}{ Neotanaidae } \\
\hline Neotanais & $1(1)$ & $1(1)$ & - & $2(2)$ & 10 & 7 & $474-1645$ \\
\hline \multicolumn{8}{|l|}{ Nototanaidae } \\
\hline Nototanais & - & $1(0)$ & - & $1(0)$ & 5 & 5 & 806 \\
\hline \multicolumn{8}{|l|}{ Pseudotanaidae } \\
\hline Pseudotanais & $3(3)$ & $4(4)$ & $5(5)$ & $11(11)$ & 47 & 22 & $365-3490$ \\
\hline \multicolumn{8}{|l|}{ Tanaellidae } \\
\hline Arthrura & - & $1(0)$ & - & $1(0)$ & 25 & 25 & $979-1645$ \\
\hline Tanaella & $1(1)$ & $1(1)$ & $1(1)$ & $3(3)$ & 5 & 3 & $474-3380$ \\
\hline \multicolumn{8}{|l|}{ Typhlotanaidae } \\
\hline Larsenotanais & $1(1)$ & $1(1)$ & - & $1(1)$ & 7 & 7 & 474-979 \\
\hline Meromonakantha & - & - & $1(0)$ & $1(0)$ & 4 & 4 & $3380-3490$ \\
\hline Paratyphlotanais & $1(0)$ & $1(1)$ & $1(1)$ & $2(1)$ & 6 & 5 & $365-3490$ \\
\hline Peraeospinosus & - & $1(1)$ & - & $1(1)$ & 1 & 1 & 1645 \\
\hline Pulcherella & - & - & $3(3)$ & $3(3)$ & 11 & 8 & $3380-3490$ \\
\hline Typhlotanais & $4(3)$ & $7(6)$ & $3(3)$ & $13(11)$ & 24 & 4 & $474-3490$ \\
\hline \multicolumn{8}{|l|}{ Incertae sedis } \\
\hline Insociabilitanais & - & $1(1)$ & $1(1)$ & $2(2)$ & 4 & 3 & 979-3212 \\
\hline Stenotanais & - & $1(1)$ & - & $1(1)$ & 1 & 1 & 1645 \\
\hline Tanaopsis & $1(1)$ & $1(1)$ & - & $1(1)$ & 5 & 5 & $364-806$ \\
\hline
\end{tabular}



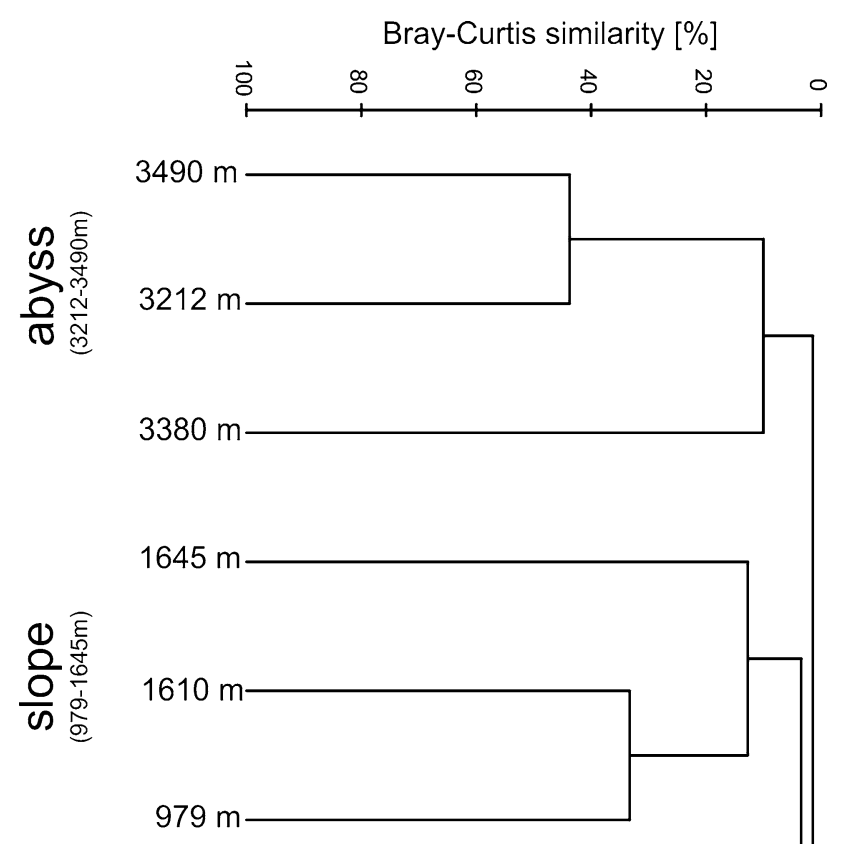

$806 \mathrm{~m}$

$524 \mathrm{~m}$
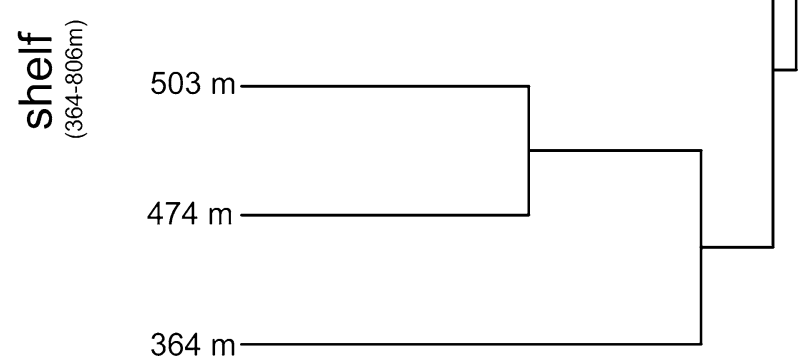

Fig. 2 Dendrogram of EBS samples for the Bray-Curtis similarity, presence/absence transformed data and group average grouping method (stations are labeled by maximum depth)

arctowskii Jóźwiak \& Błażewicz-Paszkowycz, 2011, Paranarthrura fortispina (Sieg, 1986), Paratyphlotanais alveolus (Błażewicz-Paszkowycz, 2007), Typhlotanais greenwichensis (Shiino, 1970), Typhlotanais squamiger (Błażewicz-Paszkowycz, 2007), Zoidbergus paragracilis (Kudinova-Pasternak, 1975) and formally undescribed Collettea sp. C (Błażewicz-Paszkowycz and Larsen 2005). Four species were classified as family incertae sedis. The most speciose genera were Typhlotanais (13 species), Pseudotanais (11 species), Paraleptognathia (eight species) and Leptognathia (five species). The most speciose family was Typhlotanaidae with 21 species in total.

Cluster analysis clearly separated the faunas of the three depth zones (shelf, slope and abyss), although the similarity level was low (Fig. 2). The abyssal was separated from the shallower areas. The shelf break and slope stations were grouped in one cluster; however, shelf fauna $(365-524 \mathrm{~m})$ was further separated from the slope fauna $(979-1645 \mathrm{~m})$. The shallowest sample $(806 \mathrm{~m})$ from the upper slope was grouped with shelf samples. The tanaidacean fauna of each of those zones was distinct. Only four species (5.4\% of all species) were common to shelf and slope, but three of them were found only in samples from the upper slope (806-979 m). Moreover, only three species $(4.1 \%)$ were common to abyssal depths and slope and only one species (1.3\%) occurred from shelf to abyss. Most of the species occurred in extremely low abundance. Singletons constituted $40 \%$ of the species, while doubletons represented another $20 \%$ of the material. The highest total abundance of a single species did not exceed 25 individuals, but in most of the genera, this value ranged from 1 to 5 individuals (Table 2). Total number of individuals per sample did not exceed 50, while the highest number of species in one sample equaled 21 . The highest number of individuals per $1000 \mathrm{~m}$ was 131 (Table 1).

On the shelf $(365-524 \mathrm{~m}), 20$ species were recorded. The most speciose genera were Pseudotanais and Paraleptognathia (each with three species). The number of species recorded on the slope was higher (28 species) than on the shelf. The most speciose genus was Typhlotanais (six species). The abyssal group was the most diverse with 31 species recorded, despite the fact that only three samples were collected from that depth range. The most
Fig. 3 Species accumulation curve for the tanaidacean fauna sampled via RV Tangaroa (EBS samples) in the western Ross Sea

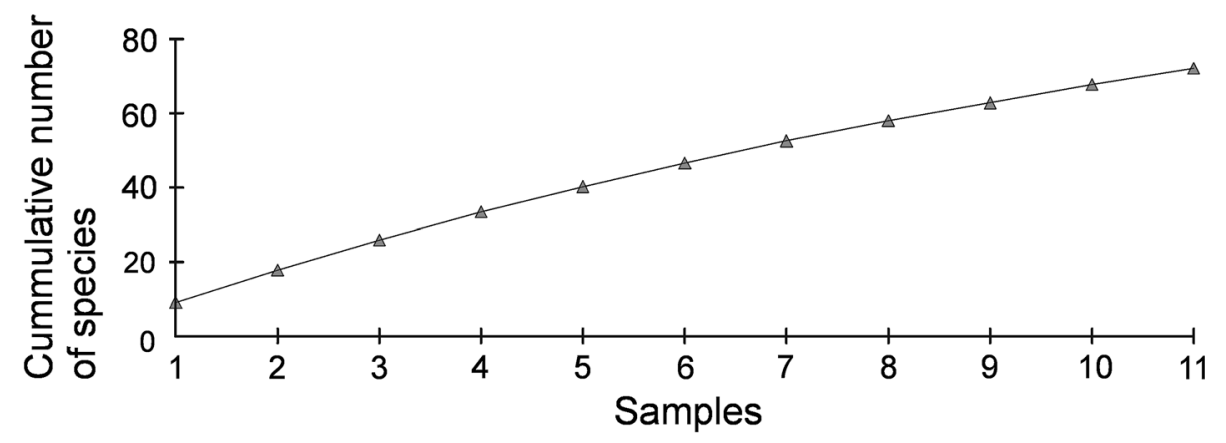


speciose genera were Paratyphlotanais, Pseudotanais and Pulcherella (each with three species). The highest number of species known to science was found in the abyssal zone (six species) and on the slope (six species). Only two of the previously known species were recorded on the shelf. The species accumulation curve demonstrated undersampling of the studied area (Fig. 3).

\section{Discussion}

Ingels et al. (2012) listed isopods and amphipods among the five major groups in the Southern Ocean that act as key contributors to the Antarctic diversity. The current number of isopod and amphipod species described from the Southern Ocean is higher than tanaidaceans (De Broyer et al. 2011), but most recent studies (e.g., Pabis et al. 2015) demonstrated that the species richness of the Antarctic shelf tanaidacean fauna is highly underestimated and equally poorly recognized as that in the deep sea (Brandt et al. 2007). The list provided as an outcome of the Census of the Antarctic Marine Life included 160 species of Tanaidacea in the Southern Ocean (De Broyer et al. 2011), and another 11 species were described recently from the deep sea (Larsen 2013; Larsen et al. 2013; Larsen and Araújo-Silva 2014). The latest study from the Amundsen and Scotia Seas extended that list by about $50 \%$. Almost 80 new species from 36 samples were identified, although still not formally described (Pabis et al. 2015). Our results from the Ross Sea supplement this list by another 62 species identified from relatively low numbers of specimens and from a modest 11 samples.

The extremely high species richness and low abundance of tanaidaceans apparently indicates an extensive radiation of this group in the Antarctic. Tanaidaceans most probably inhabit all benthic microhabitats, and their low dispersal abilities and reproduction mode result in limited gene flow across even moderate distances (Błażewicz-Paszkowycz et al. 2012; Ingels et al. 2012). Those features may place Tanaidacea among most speciose groups of macrofauna of the Southern Ocean, and they, consequently, may represent an important element for biodiversity inventories and the discussions on climate change influence on benthic fauna.

Historical as well as most recent studies, conducted in various regions of the world (e.g., Hansen 1913; Larsen 2005; Bamber and Błażewicz-Paszkowycz 2013; Błażewicz-Paszkowycz et al. 2015; Poore et al. 2014) confirm that high species richness of Tanaidacea observed in the Ross Sea is a typical pattern rather than an unusual phenomenon. In the New Zeland, samples taken from bathyal depths by means of the same gear revealed 37 of 48 tanaidacean species new to science (Lörz 2011). In the Weddell Sea, known for its rich tanaidacean fauna (Sieg 1986a), the number of tanaidacean species caught in the supranet of the EBS varied from one to ten (Linse et al. 2002; Lörz and Brandt 2003), although less samples were analyzed than in the material presented in this paper. This high taxonomical novelty in any of the studied new collection supports the estimations that the number of Tanaidacea species might exceed 40,000 worldwide (Appeltans et al. 2012).

Low mobility and virtually direct development makes Tanaidacea potentially vulnerable to environmental changes. Results of the studies on the other Southern Ocean invertebrates demonstrated their low tolerance to warming especially when concerning low activity taxa (Peck et al. 2009). This fact is quite important in the context of the latest discussion about the possibility of describing new taxa before they go extinct, especially in case of poorly studied groups such as, e.g., tanaidaceans (Mora et al. 2011; Costello et al. 2013). The comprehensive recognition of diversity of those taxa is crucial for understanding the influences of climate change on benthic fauna and the recognition of potential future changes in their bathymetric distribution, range shifts and degree of connectivity between major Southern Ocean basins. The urgent need for meaningful biodiversity assessments was listed among priority tasks of current Antarctic science (Kennicutt et al. 2015) and an important issue for monitoring programs such as the Southern Ocean Observing System (SOOS) (Brandt et al. 2014). Any new data, especially from the still insufficiently sampled deep sea, contribute to the further understanding of tanaidacean zoogeography and distribution patterns. These are crucial for an accurate assessment of the zoogeographical affinities between various regions of the Southern Ocean (Błażewicz-Paszkowycz 2014). Only 12 species from our material were previously known. Most of them were found in various locations in the West Antarctic including: Scotia Sea, Weddell Sea, Amundsen Sea and region of the Antarctic Peninsula (Sieg 1986b; Kudinova-Pasternak 1975; Jóźwiak and Błażewicz-Paszkowycz 2007, 2011; Błażewicz-Paszkowycz 2014). Only some of them like $N$. antarcticus, $C$. antarctica, $P$. arctowskii were also previously recorded in the East Antarctic (Sieg 1986b; Kudinova-Pasternak 1975; Jóźwiak and Błażewicz-Paszkowycz 2011).

Results of the recent study of the Ross Sea shelf (80-500 $\mathrm{m}$ depth range) tanaidacean fauna along the Victoria Land Transect (Błażewicz-Paszkowycz and Siciński 2014) demonstrated the presence of relatively low numbers of the new taxa. Only eight species were previously undescribed. On the other hand, results of the present study are congruent with preliminary assessment of isopod richness in the material from the same RV Tangaroa 
cruise, with about $70 \%$ species new to science (Lörz et al. 2013). At the same time, abundance of isopods was one order of magnitude higher. Tanaidacean abundance was very low, and singletons and doubletons constituted $60 \%$ of the material. This implies a need for more adequate assessment of the tanaidacean rarity in the Southern Ocean, based on more extensive quantitative sampling, as it was already emphasized in other studies of the deep-sea tanaidacean fauna (Błażewicz-Paszkowycz et al. 2015), and in the studies of the other Southern Ocean peracarids (Kaiser et al. 2007).

Despite the fact that the sampled area was relatively large (Fig. 1) and the number of samples was very limited (Table 1), our results indicated that each of those depth zones is inhabited by a distinct set of species. Nevertheless, further studies should be based on higher sampling effort that would address possible sampling bias. Similar results were also obtained for the bryozoans, isopods and ostracods in the Weddell Sea (Kaiser et al. 2011). For example, the number of bryozoan species common to both, the shelf and the slope was $26 \%$, while the percentage of ostracod species common to both, the slope and the abyss was $36 \%$. The Scotia Sea analyzed in the same study showed that the slope fauna is to some point transitional between the shelf and the abyss and that there is no segregation of faunas (Kaiser et al. 2011). In case of the Ross Sea tanaidaceans, the number of species shared between the three depth zones was very low. Błażewicz-Paszkowycz and Siciński (2014) showed also that the Ross Sea shelf tanaidacean fauna has high species richness, although three quarters of the 40 species recorded in that study were previously known to science and those results further enhance differences between shelf and slope fauna of this basin.

It is quite surprising that the abyssal sites were the most speciose; however, the total number of species recorded on the slope was only slightly lower. Brandt et al. (2007) demonstrated high diversity of Antarctic abyssal fauna, although slope depths with much more dynamic and unpredictable environmental conditions create a high variety of habitats, and are important biodiversity hot spots in the deep sea (Rex and Etter 2010). Nevertheless, it is worth mentioning that this observed pattern might be different for each taxonomic group or region studied (Kaiser et al. 2011; McCallum et al. 2015). For example, Linse et al. (2007) has demonstrated that benthic macrofauna in the Weddell Sea between 1000 and $5000 \mathrm{~m}$ varied between the sites but not with depth. Further research should include the problems of specificity of species composition, proper assessment of the role of rare species and patterns associated with diversity of various microhabitats which is not possible in case of samples collected with use of sampling gear like an epibenthic sled or various types of dredges.
Acknowledgments The collection of the samples was funded by the New Zealand Government under the New Zealand International Polar Year Census of Antarctic Marine Life Project. We gratefully acknowledge project governance provided by the Ministry of Fisheries Science Team and the Ocean Survey 20/20 CAML Advisory Group (Land Information New Zealand, Ministry of Fisheries, Antarctica New Zealand, Ministry of Foreign Affairs and Trade, and National Institute of Water and Atmospheric Research). Analysis of tanaidacean fauna was supported by National Science Center project titled "Bathyal, abyssal and hadal tanaidacean fauna-exploring the deep-sea biodiversity" (2014/13/B/NZ8/04702).

Open Access This article is distributed under the terms of the Creative Commons Attribution 4.0 International License (http://creativecommons.org/licenses/by/4.0/), which permits unrestricted use, distribution, and reproduction in any medium, provided you give appropriate credit to the original author(s) and the source, provide a link to the Creative Commons license, and indicate if changes were made.

\section{References}

Appeltans W, Ahyong ST, Anderson G, Angel MV, Artois T, Bailly $\mathrm{N}$, Bamber R, Barber A, Bartsch I, Berta A, BłażewiczPaszkowycz M, Bock P, Boxshall G, Boyko CB, Brandão SN, Bray RA, Bruce NL, Cairns SD, Chan TY, Cheng L, Collins AG, Cribb T, Curini-Galletti M, Dahdouh-Guebas F, Davie PJF, Dawson MN, De Clerck O, Decock W, De Grave S, de Voogd NJ, Domning DP, Emig CC, Erséus C, Eschmeyer W, Fauchald K, Fautin DG, Feist SW, Fransen CHJM, Furuya H, GarciaAlvarez O, Gerken S, Gibson D, Gittenberger A, Gofas S, Gómez-Daglio L, Gordon DP, Guiry MD, Hernandez F, Hoeksema BW, Hopcroft RR, Jaume D, Kirk P, Koedam N, Koenemann S, Kolb JB, Kristensen RM, Kroh A, Lambert G, Lazarus DB, Lemaitre R, Longshaw M, Lowry J, Macpherson E, Madin LP, Mah C, Mapstone G, McLaughlin PA, Mees J, Meland K, Messing CG, Mills CE, Molodtsova TN, Mooi R, Neuhaus B, Ng PKL, Nielsen C, Norenburg J, Opresko DM, Osawa M, Paulay G, Perrin W, Pilger JF, Poore GCB, Pugh P, Read GB, Reimer JD, Rius M, Rocha RM, Saiz-Salinas JI, Scarabino V, Schierwater B, Schmidt-Rhaesa A, Schnabel KE, Schotte M, Schuchert P, Schwabe E, Segers H, Self-Sullivan C, Shenkar N, Siegel V, Sterrer W, Stöhr S, Swalla B, Tasker ML, Thuesen EV, Timm T, Todaro MA, Turon X, Tyler S, Uetz P, van der Land J, Vanhoorne B, van Ofwegen LP, van Soest RWM, Vanaverbeke J, Walker-Smith G, Walter TC, Warren A, Williams GC, Wilson SP, Costello MJ (2012) The magnitude of global marine species diversity. Curr Biol 22:2189-2202. doi:10. 1016/j.cub.2012.09.036

Arrigo KR, van Dijken GL, Bushinsky S (2008) Primary production in the Southern Ocean, 1997-2006. J Geophys Res 113:c08004. doi:10.1029/2007JC004551

Bamber R, Błażewicz-Paszkowycz M (2013) Another inordinate fondness: diversity of the tanaidacean fauna of Australia, with description of three new taxa. J Nat Hist 47:1767-1789. doi:10. 1080/00222933.2012.742164

Barnes DKA (2008) A benthic richness hot spot in the Southern Ocean: slope and shelf cryptic benthos of Shag Rocks. Antarct Sci 20:263-270. doi:10.1017/S0954102008001089

Berkman PA, Cattaneo-Vietti R, Chiantore M, Howar-Williams C, Cummings V, Kvitek R (2005) Marine research in the role Latitudinal Gradient Project along Victoria Land, Antarctica. Sci Mar 69:57-63 
Blake JA, Narayanswamy BE (2004) Benthic infaunal communities across the Weddell Sea Basin and South Sandwich Slope, Antarctica. Deep Sea Res II 51:1797-1815. doi:10.1016/j.dsr2. 2004.07.014

Błażewicz-Paszkowycz M (2014) Tanaidacea. In: De Broyer C, Koubbi P, Griffiths H, Danis B, David B (eds) Biogeographic Atlas of the Southern Ocean. Scientific Committee on Antarctic Research, Cambridge, pp 173-180

Błażewicz-Paszkowycz M, Bamber R, Anderson G (2012) Diversity of Tanaidacea (Crustacea: Peracarida) in the World's OceansHow far have we come? PLoS One 7:e33068. doi:10.1371/ journal.pone. 0033068

Błażewicz-Paszkowycz M, Pabis K, Jóźwiak P (2015) Tanaidacean fauna of the Kuril-Kamchatka Trench and adjacent abyssal plain-abundance, diversity and rare species. Deep Sea Res II 111:325-332. doi:10.1016/j.dsr2.2014.08.021

Błażewicz-Paszkowycz M, Larsen K (2005) New species of the genus Collettea (Peracarida: Tanaidacea) from the southern seas and Antarctica. Zootaxa 1085:1-19

Błażewicz-Paszkowycz M, Siciński J (2014) Diversity and distribution of Tanaidacea (Crusatacea) along the Victoria Land Transect (Ross Sea, Sothern Ocean). Polar Biol 37:19-529. doi:10.1007/s00300-014-1452-7

Brandt A, Gooday AJ, Brandao SN, Brix S, Brökeland W, Cedhagen T, Choudhury M, Cornelius N, Danis B, De Mesel I, Diaz RJ, Gillian DC, Ebbe B, Howe JA, Janussen D, Kaiser S, Linse K, Malyutina M, Pawlowski J, Raupach M, Vanreusel A (2007) First insights into the biodiversity and biogeography of the Southern Ocean deep sea. Nature 447:307-311

Brandt A, Griffiths H, Gutt J, Linse K, Schiaparelli S, Ballerini T, Danis B, Pfannukuche O (2014) Challenges of deep-sea biodiversity assessments in the Southern Ocean. Adv Polar Sci 25:204-212. doi:10.1038/nature05827

Brenke N (2005) An epibenthic sledge for operations on marine soft bottom and bedrock. Mar Technol Soc J 39:10-21. doi:10.4031/ 002533205787444015

Clarke KR, Warwick RM (2001) Change in marine communities: an approach to statistical analysis and interpretation. Plymouth Marine Laboratory, Plymouth

Clarke A, Griffiths HJ, Linse K, Barnes DKA, Crame JA (2007) How well do we know the Antarctic marine fauna? A preliminary study of macroecological and biogeographical patterns in Southern Ocean gastropod and bivalve mollusks. Divers Distrib 13:620-632. doi:10.1371/journal.pone.0011683

Costello MJ, May RM, Stork NE (2013) Can we name Earth's species before they go extinct? Science 339:413-416. doi:10.1126/ science. 1230318

Cummings VJ, Thrush SF, Chiantore M, Hewitt JE, Cattaneo-Vietti R (2010) Macrobenthic communities of the north-western Ross Sea shelf: links to depth, sediment characteristics and latitude. Antarct Sci 22:793-804. doi:10.1017/S0954102010000489

Dayton P, Robilliard G, Paine R, Dayton L (1974) Biological accommodation in the benthic community at McMurdo Sound Antarctica. Ecol Monogr 44:105-128

Dayton PK, Oliver JS (1977) Antarctic soft-bottom benthos in oligotrophic and eutrophic environments. Science 197:55-58

De Broyer C, Danis B, Allcock L, Angel M, Arango C, Artois T, Barnes D, Bartsch I, Bester M, Błachowiak-Samołyk K, Błażewicz M, Bohn J, Brandt A, Brandao SN, David B, de Salas M, Eleaume M, Emig C, Fautin D, George KH, Gillan D, Gooday A, Hopcroft R, Jangoux M, Janussen D, Koubbi P, Kouwenberg J, Kuklinski P, Ligowski R, Lindsay D, Linse K, Longshaw M, Lopez- Gonzalez P, Martin P, Munilla T, Muhlenhardt-Siegel U, Neuhaus B, Norenburg J, Ozouf-Costaz C, Pakhomov E, Perrin W, Petryashov V, Pena-Cantero AL, Piatkowski U, Pierrot-Bults A, Rocka A, Saiz-Salinas J, Salvini-
Plawen L, Scarabino V, Schiaparelli S, Schrodl M, Schwabe E, Scott F, Siciński J, Siegel V, Smirnov I, Thatje S, Utevsky A, Vanreusel A, Wiencke C, Woehler E, Zdzitowiecki K, Zeidler W (2011) How many species in the Southern Ocean? Towards a dynamic inventory of the Antarctic marine species. Deep-Sea Res II 58:5-17. doi:10.1016/j.dsr2.2010.10.007

Gambi MC, Castelli A, Guizzardi M (1997) Polychaete populations of the shallow soft bottoms off Terra Nova Bay (Ross Sea, Antarctica): distribution, diversity and biomass. Polar Biol $17: 199-210$

Griffiths HJ (2010) Antarctic marine biodiversity-What do we know about the distribution of life in the Southern Ocean? PloS One 5:e11683. doi:10.1371/journal.pone.0011683

Griffiths H, van de Putte A, Danis B (2014) Data distribution: Patterns and implications. In: De Broyer C, Koubbi P, Griffiths H, Danis B, David B (eds) Biogeographic Atlas of the Southern Ocean. Scientific Committee on Antarctic Research, Cambridge, pp 16-17

Griffiths HJ, Danis B, Clarke A (2011) Quantifying Antarctic marine biodiversity: the SCAR-MarBIN data portal. Deep-Sea Res II 58:18-29. doi:10.1016/j.dsr2.2010.10.008

Gutt J (2001) On the direct impact of ice on marine benthic communities, review. Polar Biol 24:553-564. doi:10.1007/ s003000100262

Hansen HJ (1913) Crustacea Malacostraca. II. Danish Ingolf-Exped 33:1-145

Hilbig B (2004) Polychaetes of the deep Weddell and Scotia Seascomposition and zoogeographical links. Deep-Sea Res II 51:1817-1825. doi:10.1016/j.dsr2.2004.07.015

Ingels J, Vanreusel A, Brandt A, Catarino AI, David B, De Ridder C, Dubois P, Gooday AJ, Martin P, Pasotti F, Robert H (2012) Possible effects of global environmental changes on Antarctic benthos: a synthesis across five major taxa. Ecol Evol 2:453-485. doi:10.1002/ece3.96

Jóźwiak P, Błażewicz-Paszkowycz M (2007) Apseudomorpha (Malacostraca, Tanaidacea) of the ANDEEP III Antarctic Expedition. Zootaxa 1610:1-25

Jóźwiak P, Błażewicz-Paszkowycz M (2011) New records of the family Agathotanaidae (Crustacea: Tanaidacea) in the Antarctic, with remarks on Arthrura monacantha (Vanhöffen, 1914). Zootaxa 2785:32-52

Kaiser S, Barnes DKA (2008) Southern Ocean deep-sea biodiversity: sampling strategies and predicting responses to climate change. Clim Res 37:165-179. doi:10.3354/cr00761

Kaiser S, Barnes DKA, Brandt A (2007) Slope and deep-sea abundance across scales: Southern Ocean isopods show how complex the deep sea can be. Deep-Sea Res II 54:1776-1789. doi:10.1016/j.dsr2.2007.07.006

Kaiser S, Barnes DKA, Sands CJ, Brandt A (2009) Biodiversity of an unknown Antarctic Sea: assessing isopod richness and abundance in the first benthic survey of the Amundsen continental shelf. Mar Biodivers 39:27-43. doi:10.1007/ s12526-009-0004-9

Kaiser S, Griffiths HJ, Barnes DKA, Brandao SN, Brandt A, O'Brien PE (2011) Is there a distinct continental slope fauna in the Antarctic? Deep-Sea Res II 58:91-104. doi:10.1016/j.dsr2.2010. 05.017

Kennicutt MC, Chown SL, Cassano JJ, Liggett D, Peck LS, Massom R, Rintoul SR, Storey J, Vaughan DG, Wilson TJ, Allison I, Ayton J, Badhe R, Baeseman J, Barret PJ, Bell RE, Bertler N, Bo S, Brandt A, Bromwich D, Cary S, Clark MS, Convey P, Costa ES, Cowan D, Deconto R, Dunbar R, Elfring C, Escutia C, Francis J, Fricker HA, Fukuchi M, Gilbert N, Gutt J, Havermans C, Hik D, Hosie G, Jones C, Kim YD, Le Maho Y, Lee SH, Leppe M, Leitchenkov G, Li X, Lipenkov V, Lochte K, LopezMartinez J, Ludecke C, Lyons W, Marenssi S, Miller H, 
Morozova P, Naish T, Nayak S, Ravindra R, Retamales J, Ricci CA, Rogan-Finnemore M, Ropert-Coudert Y, Samah AA, Sanson L, Scambos T, Schloss IR, Shiraishi K, Siegert MJ, Simoes JC, Storey B, Sparrow MD, Wall DH, Walsh JC, Wilson G, Winther JG, Xavier JC, Yang H, Sutherland WJ (2015) A roadmap for Antarctic and Southern Ocean science for the next two decades and beyond. Antarct Sci 27:3-18. doi:10.1017/ S0954102014000674

Kudinova-Pasternak RK (1975) Tanaidacea (Crustacea, Malacostraca) from the Atlantic sector of Antarctic and Subantarctic. Trans Inst Oceanol Acad Sci USSR 103:194-229

Larsen K (2005) Deep-sea Tanaidacea (Peracarida) from the Gulf of Mexico. Leiden, Brill

Larsen K (2013) The ANDEEP Tanaidacea (Crustacea: Peracarida) revisited II: the family Anarthruridae and family incertae sedis, with descriptions of three new species and the erection of a new genus. Zootaxa 3694:367-380

Larsen K, Araújo-Silva CL (2014) The ANDEEP Tanaidacea (Crustacea: Peracarida) revisited III: the family Akanthophoreidae. Zootaxa 3796:237-264

Larsen K, Bird G, Ota M (2013) The ANDEEP Tanaidacea (Crustacea: Peracarida) revisited I: the family Agathotanaidae Lang, with description of four new species. Zootaxa 3630:424-444

Linse K, Brandt A, Hilbig B, Wegener G (2002) Composition and distribution of suprabenthic fauna in the southeastern Weddell Sea and off King George Island. Antarct Sci 14:3-10

Linse K, Brandt A, Bohn JM, Danis B, De Broyer C, Ebbe B, Heterier V, Janussen D, Lopez-Gonzalez PJ, Schuller M, Schwabe E, Thomson MRA (2007) Macro- and megabenthic assemblages in the bathyal and abyssal Weddell Sea (Southern Ocean). DeepSea Res Part II 54:1848-1863. doi:10.1016/j.dsr2.2007.07.011

Lörz AN (2011) Biodiversity of an unknown New Zealand habitat: bathyal invertebrate assemblages in the benthic boundary layer. Mar Biodivers 41:299-312. doi:10.1007/s12526-010-0064-x

Lörz AN, Brandt A (2003) Diversity of Peracarida (Crustacea, Malacostraca) caught in a suprabenthic sampler. Antarct Sci $15: 433-438$

Lörz AN, Kaiser S, Bowden D (2013) Macrofaunal crustaceans in the benthic boundary layer from the shelf break to abyssal depths in the Ross Sea (Antarctica). Polar Biol 36:445-451. doi:10.1007/ s00300-012-1269-1

McCallum AW, Woolley S, Błażewicz-Paszkowycz M, Browne J, Gerken S, Kloser R, Poore GCB, Staples D, Syme A, Taylor J, Walker-Smith G, Williams A, Wilson RS (2015) Productivity enhances benthic species richness along an oligotrophic Indian Ocean continental margin. Global Ecol Biogeogr 24:462-471. doi:10.1111/geb.12255

Mora C, Tittensor DP, Adl S, Simpson AGB, Worm B (2011) How many species are there on Earth and in the ocean. PLoS Biol 9:e1001127. doi:10.1371/journal.pbio.1001127

Pabis K, Błażewicz-Paszkowycz M, Jóźwiak P, Barnes DKA (2015) Tanaidacea of the Amundsen and Scotia Seas: an unexplored diversity. Antarct Sci 27:19-30. doi:10.1017/ S0954102014000303

Pardo PC, Perez FF, Velo A, Gilcoto M (2012) Water masses distribution in the Southern Ocean: improvement of an extended
OMP (eOMP) analysis. Prog Oceanogr 103:92-105. doi:10. 1016/j.pocean.2012.06.002

Peck LS, Clark MS, Morley SA, Massey A, Rossetti H (2009) Animal temperature limits and ecological relevance: effects of size, activity and rates of change. Funct Ecol 23:248-256. doi:10. 1111/j.1365-2435.2008.01537.x

Piazza P, Błażewicz-Paszkowycz M, Ghiglione C, Alvaro MC, Schnabel K, Schiaparelli S (2014) Distributional records of Ross Sea (Antarctica) Tanaidacea from museum samples stored in the collections of the Italian National Antarctic Museum (MNA) and the New Zealand National Institute of Water and Atmospheric Research (NIWA). ZooKeys 451:49-60. doi:10.3897/zookeys. 451.8373

Poore GCB, Avery L, Błażewicz-Paszkowycz M, Browne J, Bruce NL, Gerken S, Glasby C, Greaves E, McCallum AW, Staples D, Syme A, Taylor J, Walker-Smith G, Warne M, Watson C, Williams A, Wilson RS, Woolley S (2014) Invertebrate diversity of the unexplored marine western margin of Australia: taxonomy and implications for global biodiversity. Mar Biodivers. doi:10. 1007/s12526-014-0255-y

Post AL, Beaman RJ, O’Brien PE, Eleaume M, Riddle MJ (2011) Community structure and benthic habitats across the George $\mathrm{V}$ shelf, East Antarctica: trends through space and time. Deep-Sea Res II 58:105-118. doi:10.1016/j.dsr2.2010.05.020

Rehm P, Thatje S, Mühlenhardt-Siegel U, Brandt A (2007) Composition and distribution of the peracarid crustacean fauna along a latitudinal transect off Victoria Land (Ross Sea, Antarctica) with special emphasis on the Cumacea. Polar Biol 30:871-881. doi:10.1007/s00300-006-0247-x

Rex MA, Etter RJ (2010) Deep-sea biodiversity. Harvard University Press, Cambridge

Schiaparelli S, Ghiglione C, Alvaro MC, Griffiths HJ, Linse K (2014) Diversity, abundance and composition in macrofaunal mollusks from the Ross Sea (Antarctica): results of fine-mesh sampling along a latitudinal gradient. Polar Biol 37:859-877. doi:10.1007/ s00300-014-1487-9

Sieg J (1983) Tanaidomorpha (Crustacea: Tanaidacea) from the Ross Sea, Antarctica. J R Soc NZ 13:395-418

Sieg J (1986a) Tanaidacea (Crustacea) von der Antarktis und Subantarktis. II. Tanaidacea gesammelt von Dr. J.W. Wägele während der Deutschen Antarktis Expedition 1983. Mitt Zool Mus Univ Kiel 2:1-80

Sieg J (1986b) Crustacea Tanaidacea of the Antarctic and the Subantarctic. 1. On material collected at Tierra del Fuego, Isla de los Estados, and the west coast of the Antarctic Peninsula. In: Korniker LS (ed) Biology of the Antarctic Seas 18. Vol. 45 in the Antarctic Research Series. American Geophysical Union, Washington, $\mathrm{p} 1-180$

Smith WO Jr, Sedwick PN, Arrigo KR, Ainley DG, Orsi AH (2012) The Ross Sea in a sea of change. Oceanography 25:90-103. doi:10.5670/oceanog. 2012.80

Thatje S (2012) Effects of capability for dispersal on the evolution of diversity in Antarctic benthos. Integr Comp Biol 52:470-482. doi:10.1093/icb/ics105

Thatje S, Hillenbrand CD, Larter R (2005) On the origin of Antarctic marine benthic community structure. Trends Ecol Evol 20:534-540. doi:10.1016/j.tree.2005.07.010 